\title{
Four Levels of Organization of Educational Activity of Educational Service Providers
}

\author{
Valery Okulich-Kazarin \\ School of Entrepreneurship, Wroclaw University of Environmental and Life Sciences, Poland
}

Received June 10, 2020; Revised June 22, 2020; Accepted July 20, 2020

\section{Cite This Paper in the following Citation Styles}

(a): [1] Valery Okulich-Kazarin , "Four Levels of Organization of Educational Activity of Educational Service Providers," Universal Journal of Educational Research, Vol. 8, No. 10, pp. 4870 - 4876, 2020. DOI: 10.13189/ujer.2020.081059.

(b): Valery Okulich-Kazarin (2020). Four Levels of Organization of Educational Activity of Educational Service Providers. Universal Journal of Educational Research, 8(10), 4870 - 4876. DOI: 10.13189/ujer.2020.081059.

Copyright $\odot 2020$ by author, all rights reserved. Author agrees that this article remains permanently open access under the terms of the Creative Commons Attribution License 4.0 International License

\begin{abstract}
The purpose of the review was to show four levels of organization of educational activity of educational service providers. The review was carried out since January 2020 till May 2020. Above 200 publications have been explored, including in journals indexed in databases SCOPUS and Web of Science. There were following research methods used in the review: (1) methods of theoretical analysis (induction and deduction; comparative and retrospective analysis; classification; specification and generalization); (2) empirical methods (study scientific papers and normative legal acts; content analysis of relevant sources); (3) mathematical and graphical methods for data analysis of research, verification of statistical hypotheses. The results of the review have a few significant implications for science and practice. Three theoretical directions were explored: 1 . psychological sciences; 2. learning theory; 3. investment in higher education. For the first time it was shown four levels of organization of educational activity of educational service providers. The recommendations were generated for each of four levels. Some results are statistically significant (0.05).
\end{abstract}

Keywords Educational Services, Educational Activity, Management, Organization, Educational Service Provider

\section{Introduction}

The review is a small part of a common research of educational services in East European Universities. The review was carried out at the East European Scientific Group since January 2020 till May 2020. The common research was initiated in December 2016 by the East European Scientific Group. Therefore, the terminology and research methods are common to many of the author's papers related to educational services.

In this review, the author has drawn the overall picture regarding organization of educational activity of educational service providers.

These results are obtained for Universities in Eastern Europe. However, they may be very important for other weak higher education markets.

\section{Literature Review}

Above 200 publications have been explored for this review since January 2020 till May 2020. So, the literature review includes above 10 articles in journals indexed in databases SCOPUS and Web of Science.

The attitude to higher education as a service is important in the scientific literature [1-4].

In articles [5] and [6], the definitions "educational services" and "management of educational services" were considered. Many articles have showed a lot of local problems of higher educational services in Eastern Europe [7-14]. In these articles, it is proven that students do not prefer the auditory method of teaching at lectures. In article [12] it is shown that the auditory teaching method dominated at lectures. Thus, we are dealing with a contradiction between the way of lecturing and student 
preferences.

In article [6], the definition of "management of educational services" was presented as "it is organization and coordination of educational activities of providers and consumers, with the aim of meeting the established and perceived educational needs of the consumers". There you can see that the definition of "management" has two directions. There are "coordination" and "organization". These definitions correspond to the functions of management "Organization" and "Coordination".

In the article [15] it was studied in detail the features of "coordination" of educational activities of providers and consumers. The author [15] had showed three roles of Universities in the coordination of educational services at lecture:

- $\quad$ as performers of educational services;

- $\quad$ as educational institutions;

- as marketing-oriented institutions.

Universities, as providers of educational services, accept that [15]:

- teachers and students have equal rights in choosing ways to study at lectures.

- $\quad$ students, as consumers of educational services, have the right to acquire everything they see fit.

- students have the right to participate in the management of higher education, taking into account their interests.

In this review features of "organization" of educational activity of providers and consumers are studied in detail.

\section{Methods}

The review was carried out at the East European Scientific Group since January 2020 till May 2020. The practical part of the review was focused on the East European territory. If we are speaking of theoretical part, the authors relied on previous studies published before that.

The "organization" concerns Governments, higher education Ministries, pedagogical universities and academic staff. The author studies features of organization of educational activity of providers of educational services in order to satisfy the preferences of consumers. The aim of this direction is to propose measures to reduce the magnitude of the contradiction between the way of lecturing and student preferences.

The object of the review is educational services.

The subject of the review is theoretical analysis of bases of organization of educational activity of educational service providers.

The purpose of the review is to show four levels of organization of educational activity of educational service providers.

There were following research methods used in the review:
- methods of theoretical analysis (induction and deduction; comparative and retrospective analysis; classification; specification and generalization);

- empirical methods (study scientific papers and normative legal acts; content analysis of relevant sources);

- mathematical and graphical methods for data analysis of research, verification of statistical hypotheses [16].

The author had verified a pair of statistical hypotheses:

1. The Research hypothesis: auditory and visual teaching methods are used equally at lectures.

2. The Alternative hypothesis: auditory and visual teaching methods are not used equally at lectures.

The method of testing of the hypothesis about the average of General population is to calculate t-statistics [17]:

$$
\mathrm{t}_{\text {stat }}=\left(\dot{\mathrm{X}}-\mu_{0}\right) / \dot{\mathrm{S}}_{\dot{\mathrm{X}}},
$$

$\dot{\mathrm{X}}$ - Average of sample,

$\mu_{0}$ - fixed constant,

$\dot{\mathrm{S}}_{\dot{X}}-$ Average error.

After discussion, the author made a conclusion.

\section{Results}

Improving learning and teaching is among the most fundamental objectives of the Bologna Process [18]. Higher education teachers are the key players in enabling students' learning, and appropriate training in teaching skills both before being employed and throughout careers is an essential pre-requisite for a high quality education system.

For example, the article [19] examines 15 trends that are currently impacting higher education. Each trend, in and of itself, is significantly disruptive to the status quo in higher education. In combination, their impact on students, faculty, staff, parents, and the institutions themselves may be very significant.

The higher authorities should take steps to conduct programmes, such as orientation classes, seminars and refresher classes, for the teachers of higher education level [20]. And the higher authorities concerned should take the responsibility to introduce improved infrastructure facilities in order to incorporate the existing technological teaching strategies [4].

In management theory, the definition of "organization" is the establishment and maintenance of links between elements of the system [20]. Below, we will look at establishing and maintaining links between providers and consumers in higher education system.

In this review the elements of higher education system are:

- Governments and politicians, 
- $\quad$ higher education Ministries,

- $\quad$ pedagogical Universities,

- $\quad$ pedagogical personnel.

All higher education institutions are providers and students are consumers of education services. All research in the review concerns lectures only.

The theoretical analysis of bases of organization of educational activity of educational service providers will be consistently performed from the three directions:

- $\quad$ psychological sciences;

- $\quad$ learning theory;

- $\quad$ investment in higher education.

\subsection{Psychology: How Do Preferences Affect Actions?}

As A. Dallakyan writes, pleasure is the motive of each of our actions [21]. The theory of "reinforcement" also indicates that people repeat behavior that was enjoyable [22]. Bloom P. deeply explores the primal (and sometimes pretentious) enjoyment that people get from food, art, and sex in his book "How Pleasure Works" [23]. So, the desire for pleasure is deeply rooted in the human consciousness, since we have been raised since childhood, encouraging us with pleasures and sufferings. This extends to the rest of lives, because in the future, people choose pleasure and avoid suffering.

As for the educational system, it is proved that children who like to learn, learn the material better, get better marks [24]. Maybe that's why gaming teaching methods are widespread in middle and high school. After all, one of the functions of the educational game is to create a favorable atmosphere in the classroom, turning a regular lecture into a fascinating adventure [25].

Studying the communication of people, E. Berne described the three I-states that each person has [26]. "Child" is the source of our desires, appetites, needs. It is the "Child" I-state that plays when learning.

There is another reason to abandon the auditory teaching method at lectures. The fact is that listening is much more difficult than speaking. The speed of "speaking" is 4 times less than the speed of thinking [27]. Therefore, 3/4 of the brain capacity is not involved in the hearing process. These possibilities of the brain are looking for a use. And usually find it in extraneous thoughts. This fact further reduces the effectiveness of the educational process at the lectures.

Thus, various branches of psychological science reply to the question: how do preferences affect actions? You see that a person less willingly and less effectively does what he does not like. And, the person is more willingly and effectively doing what he likes.

The analysis of the above shows that at the level of pedagogical personnel, it is necessary to actively use the visual teaching method at lectures. This will increase the efficiency of the process of providing educational services.

So, this was the first term that was found for organization of educational activity of educational service providers at the level of pedagogical personnel. Of course, there are some difficulties, which are formulated as a question: how to replace the usual auditory learning method with a visual one, if the learning theory is focused on the auditory teaching method at lectures?

\subsection{Does the Auditory Teaching Method Really Dominate at Lectures in the Learning Theory?}

As established in the article [12], the auditory teaching method dominates at lectures. It has dominated for over 500 years. And all these years, the development of the learning theory has been focused on the growth of the efficiency of the auditory teaching method. Unfortunately, a content analysis of publications [28-33] did not show the existence of recommendations for a profound, revolutionary change in the learning theory. Therefore, passive listening and note-taking is the destiny of students in Eastern European universities.

Let's go back to the article [12]. Nine methods of teaching in lectures are systematized here in accordance with the learning theory. This article shows that the seven teaching methods are auditory. And two teaching methods are visual. The distribution of training methods is shown graphically in figure 1.

What does figure 1 show? Fig. 1 shows that the auditory teaching method dominates at lectures. And Fig. 1 don't give a clear idea of any correlations or guarantees. The article [12] may have omitted the teaching methods described in Arabic, Chinese, Turkish, Japanese, and other languages.

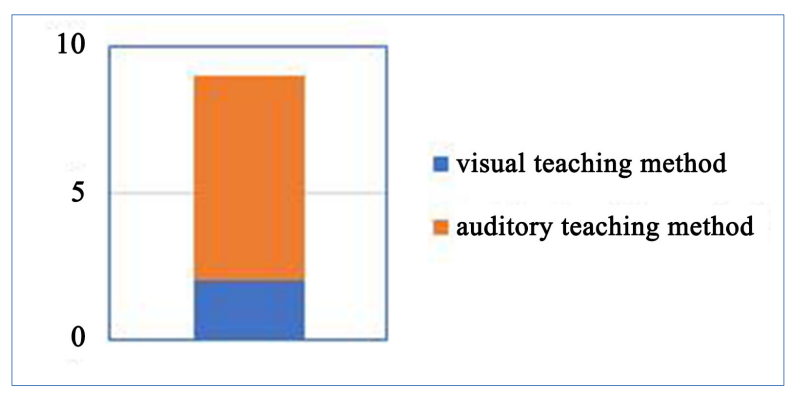

Figure 1. The distribution of training methods at lectures

Verification of statistical hypotheses can provide reliable, scientifically based statistical picture. Verification of statistical hypotheses allow to get new scientific knowledge about distribution of training methods at lectures.

Let's check statistically whether the auditory teaching method really dominates at lectures. It is assumed that if you use only the visual teaching method at lectures, then you take the value 1.0 (one). If you use only the auditory teaching method at lectures, then you take the value 0.0 (zero).

If you use the both methods at lectures in equal, then you take the value 0.5 . In other words, if the auditory 
teaching method does not dominate at lectures, you get the value 0.5 .

Based on data from article [12] and figure 1, you can calculate the average of sample $\dot{X}_{i}$ and statistical deviations $\delta_{\mathrm{i}}$ and $\delta_{\mathrm{x}-1}$. So, you have for verification of statistical hypotheses: $\mathrm{n}=9, \dot{\mathrm{X}}=0,22, \delta_{\mathrm{x}}=0,42, \delta_{\mathrm{x}-1}=$ 0,44 .

At the stage of verification of statistical hypotheses, two alternatives were considered [34]. There are a Research hypothesis and an Alternative hypothesis.

The Research hypothesis: auditory and visual teaching methods are used equally at lectures.

The Research hypothesis $\mathrm{H}_{0}: \mu=0.5$.

The Research hypothesis is as follows: auditory and visual teaching methods are used equally at lectures, if one does not take into account random deviations.

The Alternative hypothesis: auditory and visual teaching methods are not used equally at lectures.

The Alternative hypothesis $\mathrm{H}_{1}: \mu \neq 0.5$.

The Alternative hypothesis is as follows: auditory and visual teaching methods are not used equally at lectures, if one does not take into account random deviations.

Table 1 shows the results for verification of statistical hypotheses at $\mu_{0}=0.5$.

Table 1. Data for verification of statistical hypotheses

\begin{tabular}{|c|l|c|}
\hline No & Indicator & Result \\
\hline 1 & Sample size, $\mathrm{n}$ & 9 \\
\hline 2 & Selective average, $\dot{\mathrm{X}}$ & 0.22 \\
\hline 3 & Standard deviation for the sample, $\delta_{\mathrm{x}}$ & 0.42 \\
\hline 4 & Average error, $\dot{\mathrm{S}}_{\dot{\mathrm{X}}}=\delta_{\mathrm{x}} / \sqrt{\mathrm{n}}$ & 0.140 \\
\hline 5 & Value $\left|\mathrm{t}_{\mathrm{stat}}\right|$ for $\mu_{0}=0.5,\left(\dot{\mathrm{X}}-\mu_{0}\right) / \dot{\mathrm{S}}_{\dot{\mathrm{X}}}$ & 2.000 \\
\hline 6 & $\begin{array}{l}\text { Value } \mathrm{t}_{\text {tabl }} \text { for significance level } 95.0 \text { (one-way } \\
\text { interval), } \%[34, \mathrm{p} .42]\end{array}$ & 1.860 \\
\hline 7 & Result for $\mu_{0}=0.5, \mathrm{t}_{\text {stat }}>\mathrm{t}_{\text {tabl }}$ & Yes \\
\hline
\end{tabular}

Table 1 shows that the $t_{\text {stat }}$ value for $\mu_{0}=0.5$ is greater than the $t_{\mathrm{tabl}}$ value for the $95.0 \%$ significance level (lines 5 and 6). Therefore, we accept the Alternative hypothesis: the unknown average for the general population of students $\mu \neq 0.5$. This means that auditory and visual teaching methods are not used equally at lectures, if one does not take into account random deviations.

Thus, it has been proven statistically that the auditory teaching method really dominates at lectures. This result is stronger compared to the case when the Research hypothesis is accepted.

One of the core concepts for education is the "pedagogical process" [35]. The pedagogical process as integrity is considered from the standpoint of a systematic approach, which allows us to see in it primarily the pedagogical system, for example, the lecture system. The determinant of the emergence of pedagogical systems is the goal of education as a set of requirements of society in the sphere of spiritual production, as a social order [36]. This sentence is very important. This proposal gives a theoretical justification that in the theory of learning, the goal is considered as a social order. Theoretically, training is not aimed at the interests of the consumer of educational services. That is why theoretical developments in the direction of the visual learning method are absent in the learning theory of higher education.

Thus, at the level of higher education Ministries, they need to create a new social order in society. This social order should be aimed at the interests of the consumer of educational services. The social order should encourage both the use of the visual teaching method at lectures and the theory of visual learning.

Also, at the level of pedagogical Universities initiative groups of scientists should be created for new scientific research. The research should focus on developing the learning theory for the visual learning methods at lectures.

This is an interesting idea for the level of higher education Ministries: to organize training at lectures in two ways, both auditory and visual. This management decision will reflect the interests of all students without discriminating against the "auditory" minority.

In this subsection, the following terms were found for organization of educational activity of educational service providers at the levels:

- pedagogical Universities,

- $\quad$ higher education Ministries.

\subsection{Investment in Higher Education}

We now turn to the issue of finance and investment. It is obvious that scientific research in the field of visual teaching methods at lectures requires funding. No one can require professors to perform such important research at their own expense.

A content analysis of literature on investment in higher education showed the interest of scientists in this topic from the end of the 20th century and earlier [37-41]. Below are some highlights of the literature review.

First of all, the results of the study [37] show that higher education is an important driver of economic growth in advanced industrial countries, for example, like Britain.

Authors of the article [38] conducted an original, representative survey of public opinion on education and related policies in eight European countries. The analysis confirms that citizens express high levels of support for education even when they are forced to choose between education and other areas of social spending. Increasing spending on general schooling and vocational education is more popular than increasing spending on higher education and early childhood education.

The article [39] considers the current debate in Europe and recent research on the interactions between Universities and European labour markets. As the sources of funding for universities are almost entirely domestic and, in most countries, primarily governmental, Governments 
and politicians are expected to ensure that increasing public investment in higher education is justified in terms of the benefits accruing to the domestic workforce and investors.

The paper [40] discusses the issues and challenges in implementing the innovative methods of financing of the higher education system across the developed and developing countries.

And finally, the article [41] confirms that the higher education system faces specific challenges, such as the disastrous financial situation.

Thus, the study of relevant sources of information has shown a small number of publications on the topic of investment in the research of learning theory in relation to visual teaching methods at lectures. Therefore, at the level of Governments and politicians, increased public investment in higher education should be ensured in terms of the benefits received by consumers of educational services and investors. Investments in developing of visual teaching methods at lectures should be profitable for the State, investors and consumers of educational services.

Here it was established that investments in higher education should be provided at the level of Governments and politicians.

\section{Discussion}

The study showed four levels of organization of educational activity of educational service providers:

1. The level of Governments and politicians.

2. The level of higher education Ministries.

3. The level of pedagogical Universities.

4. The level of pedagogical personnel.

The theoretical analysis of bases of organization of educational activity of educational service providers was consistently performed from the three directions:

1. psychological sciences;

2. learning theory;

3. investment in higher education.

Previously, in the article [15] the theoretical analysis of bases of coordination of educational activity of educational service providers was performed from the five directions:

1. right to education;

2. academic freedom;

3. European values;

4. theory of learning and consumer rights;

5. marketing theory.

This review concludes a multi-sided theoretical study of the terms for managing educational services in Eastern European Universities.

Can we trust the results of our review?

We trust the results of our review because the used research methods are adequate to the purpose. Above 200 publications that have been explored for this study are sufficient for decision-making.

Some results are statistically significant (0.05). That is why, our results suggest that, the decision will be correct in approximately $95.0 \%$ of the cases and incorrect in $5.0 \%$ of cases only. In this sense, we have the decision-making process with accurate, controlled probability. We proved the results statistically by accepting Alternative hypotheses. This is a very strong basis for proof.

\section{Conclusions}

The purpose of the review has been achieved.

1. To achieve the purpose of the review, a theoretical analysis of the basics of organization of educational activities of educational service providers was performed. This theoretical analysis was performed from the three Sciences' points of views:

- $\quad$ psychological sciences;

- $\quad$ learning theory;

- $\quad$ investment in higher education.

2. Some results are statistically significant (0.05). In this sense, you have the decision-making process with accurate, controlled probability.

3. The recommendations how to organize educational activities of educational service providers were generated for four levels:

- At the level of pedagogical personnel, it is necessary to actively use the visual teaching method at lectures.

- At the level of pedagogical Universities new research should focus on developing the learning theory for the visual learning methods at lectures.

- At the level of higher education Ministries, it needs to create a new social order in society. The social order should encourage both the use of the visual teaching method at lectures and the theory of visual learning.

Also, at the level of higher education Ministries, it is an interesting idea to organize training at lectures in two ways, both auditory and visual.

- At the level of Governments and politicians, increased public investment in higher education should be ensured in terms of the benefits received by consumers of educational services and investors. The Governments and politicians should provide funding for research visual teaching methods at lectures.

4. It was explored three theoretical directions of organization of educational activity of educational service providers. It was shown four levels of organization of educational activity of educational 
service providers. The recommendations were generated for each of four levels.

As a result, this review has completed a series of research articles on the management of educational services in East European Universities. This review may be useful for other weak higher education markets.

The purpose of the next research is to investigate other aspects of the East European educational services market.

\section{Acknowledgements}

The author thanks reviewers for their strict and fair comments.

\section{REFERENCES}

[1] L. Bunce, A. Baird, S. E. Jones. The student-as-consumer approach in higher education and its effects on academic performance. Studies in Higher Education, 42(11): 1958-1978, 2017.

[2] Y. M. Dora, K. Kaniawati, N. Nurani. Service Quality, Student Satisfaction and Decision in Remaining Active to Study - Study at Private Universities in West Java. Universal Journal of Educational Research, 7(5A): 18-23, 2019.

[3] J. A. Douglas, A. Douglas, R. J. McClelland, et al. Understanding student satisfaction and dissatisfaction: an interpretive study in the UK higher education context, Studies in Higher Education, 40(2): 329-349, 2015.

[4] M. Jesa, E. V. Nisha. Teaching Strategies Adopted by Teachers at Higher Education Level in Kerala: A Research Report. Higher Education for the Future, 4(1): 4-11, 2017.

[5] W. Okulicz-Kozaryn. Study of definition of "educational services" in economic science. Journal of Economy and Business, 1: 180-187, 2019.

[6] W. Okulicz-Kozaryn. The definition "management of educational services". Scientific Journal Virtus, 35: 130-134, 2019.

[7] J. Alieva, et al. Management of higher education in Azerbaijan: What lectures do students prefer? Konferencja Miedzvnarodowa Naukowo-Praktyczna "Science, Research, Development, \#5: Economy. Management", Barcelona, 66-67, 2018.

[8] S. Goić, et al. Educational services management in Croatia: What lectures do students prefer? Konferencja Miedzynarodowa Naukowo-Praktyczna "Science, Research, Development \#6: Economy. Management. State and Law", Baku, 69-70, 2018.

[9] S. Isaeva, et al. Statistical Research of Preferences of Students of the Moscow Pedagogical State University in Lectures, Zeszyty Naukowe Wydziału Nauk Ekonomicznych, 1(22): 355-365, 2018.
[10] W. Okulicz-Kozaryn, O. Lapitskaya. Higher education as a business: should Belarusian Universities change the way of teaching at lectures? Journal of Economy and Business, 5(2): 5-10, 2018.

[11] V. Okulich-Kazarin. What Method of Learning do Media Students Prefer at Lectures: Auditory or Visual? Universal Journal of Educational Research, 8(6): 2660 - 2667, 2020.

[12] V. Okulich-Kazarin, M. Zhurba, O. Pagava, et al. Lecture method preferences, auditory or visual, of Ukrainian consumers of educational services: a statistical analysis, International Journal of Education and Practice, 7(2): 54-65, 2019.

[13] V. Okulich-Kazarin, M. Zhurba, Y. Bokhonkova, et al. Three Scientific Facts about Ukrainian and Polish Law-students: Verification of statistical hypotheses about their Preferences of Learning at Lectures. European Journal of Contemporary Education, 8(3): 562-573, 2019.

[14] D. Škunca, Z. Čekerevac, O. Golubyonkova, et al. Experience in assessing the priorities of consumers of educational services in universities in Serbia and Ukraine, V International Scientific Conference "Економічні та соціальні аспекти розвитку України на початку XXI століття", Odesa, 207-210, 2018.

[15] W. Okulicz-Kozaryn. Three Roles of Universities in the Management of Educational Services at Lecture. American Journal of Creative Education, 2(4): 161-172, 2019.

[16] Textbook BUS_9641_5M. Business_Statistics. Textbook for the Program "Masters of Business Administration". NY: Kingston University, 2010.

[17] E. K. Vasil'eva, V. S. Lyalin. Statistika: uchebnik dlya studentov vuzov, obuchayushchikhsya po spetsial'nostyam ekonomiki i upravleniya [Statistics: a textbook for university students enrolled in the field of economics and management]. M.: YuNITI-DANA, 2012. [in Russian]

[18] European Commission/EACEA/Eurydice. The European Higher Education Area in 2018: Bologna Process Implementation Report. Luxembourg: Publications Office of the European Union, 15, 2018.

[19] J. Dew. The Future of American Higher Education. World Futures Review, 4(4): 7-13, 2012.

[20] A. Smolkin. Management: fundamentals of the organization: Textbook. - M.: INFRA-M, 1999.

[21] A. Dallakyan. Manage pleasure. Creativity, behavioral marketing and corporations. Publishing E. [in Russian], 2016.

[22] Management. Motivational Theory of Reinforcement. https://studme.org/1766121712671/menedzhment/ motivatsionnaya_teoriya_podkrepleniya [in Russian].

[23] Why Do We Like What We Like? Part 2 of the TED Radio Hour episode Brand Over Brain, May 9, 2014.

[24] N. Yu. Bykovskaya. Learning is fun to learn well! http://rid-omsk.irooo.ru/uchimsya-vmeste/33-ot-7-do-11-le t/36-chtoby-uchjoba-byla-v-radost [in Russian], 2016.

[25] S. Miller. Psychology of the game. Transl. from English SPb.: University book, 1999. 
[26] E. Berne. Games People Play. The Psychology of Human Relationships: Trans. from English. Spb.: Lenizdat, 1992.

[27] V. P. Sheinov. The hidden human control. M.: OOO Publishing House AST, Minsk: Harvest, 2001.

[28] T. Melguizo, H. Coates. The Value of Assessing Higher Education Student Learning Outcomes. AERA Open, 3(3): 1-2, 2017.

[29] C. Boughey. From Equity to Efficiency: Access to higher education in South Africa. Arts and Humanities in Higher Education, 2(1): 65-71, 2003.

[30] J. P. Lassegard. International Student Quality and Japanese Higher Education Reform. Journal of Studies in International Education, 10(2): 119-140, 2006.

[31] J. Everett. Sustainability in higher education: Implications for the disciplines. Theory and Research in Education, 6(2): 237-251, 2008.

[32] C. R. Lorenzo, M. P. Juste. Tutorial Action as a Resource to Improve Higher Education. Journal of Hispanic Higher Education, 7(2): 144-155, 2008.

[33] P. Pjengaard. Experiments in telecommunication (two-way sound and visual communication) as a teaching method in teacher training. Research in Education, 48(1): 1-11, 1992.

[34] Textbook for the Program "Masters of Business
Administration". BUS_9641_Business_Statistics_3, USA, NY, Kingston University, 2010.

[35] V. A. Slastenin, et al. Pedagogy: A manual for students of pedagogical education institutions. 3rd ed. M.: School Press, 2000. [in Russian].

[36] T. I. Shamova, et al. Management of educational systems: Textbook for stud. higher ed. institutions / Ed. Shamova, T.I. M.: Human. ed. Center VLADOS, 2002. [in Russian].

[37] P. Whiteley. Economic Performance and Higher Education: The Lessons for Britain. The British Journal of Politics and International Relations, 14(4): 672-688, 2012.

[38] M. Busemeyer, et al. Investing in education in Europe: Evidence from a new survey of public opinion. Journal of European Social Policy, 28(1): 34-54, 2018.

[39] E. Tavoletti. Matching Higher Education with the Labour Market in the Knowledge Economy: The Much-Needed Reform of University Governance in Italy. Industry and Higher Education, 24(5): 361-375, 2010.

[40] J. Panigrahi. Innovative Financing of Higher Education: Changing Options and Implications. Higher Education for the Future, 5(1): 61-74, 2018.

[41] J. Mangold. Foundations in Germany: Higher Education. American Behavioral Scientist, 62: 1695-1714, 2018. 